\title{
PENGEMBANGAN E-MODUL INTERAKTIF BERBASIS PROYEK PADA MATA PELAJARAN SIMULASI DIGITAL KELAS X DI SMK TI BALI GLOBAL SINGARAJA
}

\author{
Winatha, K. R., Suharsono, N., dan Agustini, K. \\ Program Studi Teknologi Pembelajaran, Program Pascasarjana \\ Universitas Pendidikan Ganesha \\ Singaraja, Indonesia
}

e-mail: \{redywinatha, naswan.suharsono, agustini\}@pasca.undiksha.ac.id

\begin{abstract}
Abstrak
Penelitian ini bertujuan untuk menghasilkan produk pembelajaran berupa e-modul berbasis proyek yang valid, praktis, dan efektif bagi siswa kelas $\mathrm{X}$ semester ganjil mata pelajaran simulasi digital. Penelitian pengembangan ini didasari oleh belum tersedianya bahan ajar inovatif yang sesuai dengan tuntutan Kurikulum 2013 pada mata pelajaran simulasi digital di SMK TI Bali Global Singaraja. Prosedur pengembangan menggunakan model ADDIE yang terdiri dari lima tahap yaitu: analysis (analisis), design (desain), development (pengembangan), implementation (implementasi) dan evaluation (evaluasi).

Hasil penelitian menunjukkan bahan ajar yang dikembangkan telah memenuhi aspek validitas, kepraktisan, dan efektivitas. Hasil uji validitas menunjukkan bahwa emodul berbasis proyek beserta buku panduan berada pada kategori sangat baik berdasarkan uji coba para ahli. E-modul juga telah memenuhi aspek kepraktisan dilihat dari respon guru dan siswa terkait kemudahan penggunaan dan kemenarikan antarmuka. Hasil uji-t menunjukkan, terdapat perbedaan yang signifikan antara nilai rata-rata hasil belajar siswa sebelum dan setelah menggunakan e-modul interaktif berbasis proyek. $\mathrm{Di}$ mana nilai rata-rata posttest lebih lebih besar dari nilai rata-rata pretest dan telah memenuhi kriteria ketuntasan minimal yang telah ditetapkan. Berdasarkan hal tersebut, e-modul interaktif berbasis proyek dinilai efektif dalam meningkatkan hasil belajar.
\end{abstract}

Kata kunci: Pengembangan, e-modul, simulasi digital, pembelajaran berbasis proyek

\section{Abstract}

This research aims to develop learning product such as valid, practical and effective interactive e-module based on project for student grade $X$ first semester simulation digital lesson. This development research based by unavailable innovation education material which suitable with Curriculum 2013 on digital simulation subject in SMK TI Bali Global Singaraja. The development procedure use ADDIE model, it consist of five steps are analysis, design, development, implementation and evaluation.

The results showed teaching materials developed fulfills the validity, practicality, and effectiveness. Validity test results indicate that the interactive e-module based on project along with guide books that are in the very good category based on testing experts. Emodule also fulfills the practicality on the response of teachers and students related to ease of use and attractiveness of the interface. The results of t-test showed a significant difference between the average value of student learning outcomes before and after using the interactive e-module based on project. Where the average value posttest is greater than the average pretest and have met the minimum completeness criteria that have been set. Based on this, the e-module based interactive projects considered effective in improving learning outcomes.

Keywords: development, e-module, digital simulation, project-based learning 


\section{PENDAHULUAN}

Menjelang abad ke-21, sistem pendidikan Indonesia menghadapi tantangan yang sangat besar dalam mempersiapkan sumber daya manusia yang berkualitas dan mampu bersaing dalam Masyarakat Ekonomi ASEAN (MEA). Masyarakat Ekonomi ASEAN atau pasar bebas ASEAN Tahun 2015 menyebabkan persaingan di bursa tenaga kerja akan semakin meningkat. Di satu sisi, MEA akan menjadi kesempatan yang baik untuk menunjukkan kualitas dan kuantitas produk dan sumber daya manusia (SDM) Indonesia kepada negara-negara lain dengan terbuka, tetapi pada sisi lain dapat menjadi bumerang untuk Indonesia apabila tidak dapat dimanfaatkan dengan baik. Upaya yang tepat untuk menyiapkan sumber daya manusia yang berkualitas dan satu-satunya wadah yang dipandang dapat dimanfaatkan untuk membangun sumber daya manusia yang berkualitas dan bermutu tinggi adalah pendidikan.

Pendidikan adalah salah satu bentuk perwujudan kebudayaan manusia yang dinamis dan sarat perkembangan. Oleh karena itu, perubahan dan perkembangan pendidikan harus sejalan dengan perubahan budaya kehidupan. Perubahan ini dalam arti perbaikan pendidikan pada semua tingkat perlu terus-menerus dilakukan sebagai antisipasi kepentingan di masa depan.

Salah satu perubahan yang dilakukan pemerintah dalam bidang pendidikan adalah perubahan Kurikulum 2006 yang sering disebut sebagai Kurikulum Tingkat Satuan Pendidikan (KTSP) menjadi Kurikulum 2013 yang merupakan koreksi sekaligus penyempurnaan dan penguatan dari Kurikulum Tingkat Satuan Pendidikan (KTSP). Perubahan ini mengakibatkan adanya beberapa perubahan pada paradigma pembelajaran, salah satunya adalah perubahan orientasi pembelajaran yang semula berpusat pada guru (teacher centered) menjadi berpusat pada siswa (student centered).

Permendikbud Nomor 65 Tahun 2013 tentang standar proses pendidikan Kurikulum 2013, dinyatakan bahwa proses pembelajaran pada satuan pendidikan hendaknya diselenggarakan secara interaktif, inspiratif, menyenangkan, menantang, memotivasi peserta didik untuk berpartisipasi aktif, serta memberikan ruang yang cukup bagi prakarsa, kreativitas, dan kemandirian sesuai dengan bakat, minat, dan perkembangan fisik serta psikologis peserta didik.

Untuk itu, strategi pembelajaran yang digunakan oleh seorang guru di dalam kelasnya seharusnya ditujukan agar dapat memfasilitasi tercapainya kompetensi yang telah dirancang dalam dokumen kurikulum sehingga pada gilirannya setiap siswa mampu menjadi pembelajar yang mandiri.

Arsiti (2008) mendefinisikan belajar mandiri sebagai suatu perbuatan yang dilakukan oleh individu yang tumbuh dari dalam diri berupa tumbuhnya kesadaran akan pentingnya belajar. Berusaha sendiri untuk mencari pemecahan masalah serta pengetahuan yang menyertainya, menghasilkan pengetahuan yang benarbenar bermakna, karena dengan berusaha untuk mencari pemecahan masalah secara mandiri akan memberikan suatu pengalaman konkret, dan pengalaman ini dapat digunakan dalam memecahkan masalah serupa, karena pengalaman itu memberikan makna tersendiri bagi peserta didik (Bruner dalam Ibnu, 2014).

Implikasi utama kegiatan belajar mandiri menurut Depdiknas (2008) adalah perlunya mengoptimalkan sumber belajar dengan tetap memberikan peluang otonomi yang lebih besar kepada peserta didik dalam mengendalikan kegiatan belajarnya. Peran guru/tutor bergeser dari pemberi informasi menjadi fasilitator belajar dengan menyediakan berbagai sumber belajar yang dibutuhkan, merangsang semangat belajar, memberi peluang untuk menguji atau mempraktikkan hasil belajarnya, memberikan umpan balik tentang perkembangan belajar, dan membantu bahwa apa yang telah dipelajari akan berguna dalam kehidupannya. Untuk itulah diperlukan modul sebagai sumber belajar utama dalam kegiatan belajar mandiri.

Perkembangan teknologi yang semakin pesat, mendorong terjadinya 
perpaduan antara teknologi cetak dengan teknologi komputer dalam kegiatan pembelajaran. Modul sebagai salah satu media pembelajaran cetak, ditransformasikan penyajiannya ke dalam bentuk elektronik sehingga melahirkan istilah modul elektronik atau yang dikenal dengan istilah e-modul. Modul elektronik atau e-modul, didefinisikan sebagai suatu media pembelajaran dengan menggunakan komputer yang menampilkan teks, gambar, grafik, audio, animasi, dan video dalam proses pembelajaran (Nugraha, Subarkah, \& Sari, 2015). Modul elektronik tersusun oleh navigasi berupa link yang membuat peserta didik menjadi lebih interaktif dengan program serta dilengkapi dengan penyajian video tutorial, animasi dan audio untuk memperkaya pengalaman belajar Penggunaan e-modul pada proses pembelajaran akan menumbuhkan kreativitas, kebiasaan berpikir produktif, menciptakan kondisi aktif, efektif, inovatif dan menyenangkan (Budiarti et al, 2016).

Smeets dan Bus (2014), mengungkapkan bahwa buku elektronik yang disisipi fitur multimedia dapat memperkaya pengalaman membaca buku apabila digunakan dengan benar. Buku elektronik interaktif tampaknya menjadi alternatif terbaik yang dapat berkontribusi untuk meningkatkan pemahaman bacaan dan minat baca. Gambar-gambar bergerak (animasi) diduga dapat memfasilitasi belajar ketika animasi tersebut berhasil memfokuskan perhatian anak-anak secara visual dan relevan dengan isi buku.

Berdasarkan teori belajar konstruktivis dinyatakan bahwa belajar akan lebih bermakna ketika siswa terlibat dalam membangun pengetahuan mereka sendiri. Teori ini menekankan pada penyediaan kesempatan kepada siswa untuk membuat penilaian dan interpretasi dari situasi yang mereka alami sendiri (Hussain, 2012). Salah satu model pembelajaran inovatif yang melibatkan peserta didik dalam kegiatan pemecahan masalah dan memberi peluang pada peserta didik untuk bekerja secara otonom mengkonstruksikan cara belajar mereka sendiri, dan puncaknya akan menghasilkan produk yang bernilai dan realistik adalah model pembelajaran berbasis proyek (Buck Institute for Education dalam Ibnu, 2014).

Pendekatan pembelajaran berbasis proyek dapat dipandang sebagai salah satu pendekatan penciptaan lingkungan belajar yang dapat mendorong siswa mengkonstruksikan pengetahuan dan keterampilan secara personal. Ketika pendekatan proyek ini dilakukan secara kolaboratif dalam kelompok kecil siswa, memunculkan adanya peluang bagi siswa untuk menyampaikan ide, mendengarkan ide-ide orang lain, dan merefleksikan ide sendiri pada ide-ide orang lain. Dari perspektif teoretik ini, pendekatan belajar berbasis proyek ini memberikan alternatif lingkungan belajar otentik di mana pembelajar dapat membantu memudahkan siswa meningkatkan keterampilan mereka di dalam bekerja dan pemecahan masalah secara kolaboratif. Sebagai pendekatan pembelajaran baru, pembelajaran berbasis proyek potensial berhasil memperbaiki praktik pembelajaran pada pendidikan teknologi dan kejuruan.

Menurut Undang-undang Nomor 20 tahun 2003 pasal 15 dinyatakan tujuan SMK adalah mempersiapkan siswa agar mampu: (a) bekerja baik secara mandiri atau mengisi lowongan pekerjaan yang ada sebagai tenaga kerja tingkat menengah, sesuai dengan keahlian dan ketrampilannya, (b) memilih karir, ulet dan gigih dalam berkompetensi dan mengembangkan sikap profesional dalam bidang keahlian yang diminatinya, (c) mengembangkan diri di kemudian hari melalui jenjang pendidikan yang lebih tinggi, dan (d) membekali peserta didik dengan kompetensi-kompetensi sesuai dengan program keahlian yang dipilih.

Simulasi digital merupakan bagian dari kelompok mata pelajaran produktif yang termasuk pada dasar program keahlian (C2) di Kurikulum 2013 yang diwajibkan pada semua program keahlian kelas X Sekolah Menengah Kejuruan (SMK). Mata pelajaran ini, membekali siswa keterampilan dalam memanfaatkan teknologi informasi dan komunikasi yang pada saat ini sangat dibutuhkan dalam 
dunia kerja. Keterampilan yang dimaksud seperti pengelolaan informasi digital melalui perangkat lunak pengolah informasi (pengolah kata, angka, dan presentasi), dan komunikasi dalam jaringan (online). Selain itu, mata pelajaran ini bertujuan untuk membekali siswa agar dapat mengkomunikasikan gagasan atau konsep yang ditemukannya sendiri atau memodifikasi gagasan atau konsep yang sudah ada melalui media digital.

Mata pelajaran simulasi digital wajib dikuasai siswa dengan maksimal, tetapi pada kenyataannya diperlukan alokasi waktu yang cukup besar sehingga memerlukan manajemen waktu yang baik agar siswa dapat menguasai seluruh kompetensi dasar yang terdapat dalam silabus. Kompetensi dasar dimaksud antara lain: (1) menerapkan pengetahuan pengelolaan informasi digital melalui pemanfaatan perangkat lunak pengolah informasi, (2) menyajikan hasil penerapan pengelolaan informasi digital melalui pemanfaatan perangkat lunak pengolah informasi, (3) menerapkan pengetahuan pengelolaan informasi digital melalui pemanfaatan komunikasi daring (online), (4) menyajikan hasil penerapan pengelolaan informasi digital melalui komunikasi daring (online), (5) menerapkan pengetahuan tentang keikutsertaan dalam pembelajaran melalui kelas maya, (6) menyajikan hasil penerapan keikutsertaan dalam pembelajaran melalui kelas maya, (7) menerapkan pengetahuan perancangan METODE PENELITIAN

Model pengembangan yang digunakan dalam pengembangan e-modul interaktif ini adalah ADDIE. Pemilihan model ini didasari atas beberapa pertimbangan. Pertama, model ADDIE disajikan secara sederhana dan sistematik. Tahap-tahapan dalam model ini sudah sangat sederhana jika dibandingkan dengan model desain yang lainnya. Sifatnya yang sederhana dan terstruktur dengan sistematis, membuat model ADDIE sangat mudah dipelajari oleh pengembang. Kedua, model ADDIE memberikan kesempatan untuk melakukan visualisasi konsep, dan (8) menyajikan hasil penerapan perancangan visualisasi konsep.

Melihat begitu banyaknya kompetensi yang harus dikuasai siswa dengan alokasi waktu yang hanya 3 jam perminggu mustahil bagi siswa untuk mencapai seluruh kompetensi yang diharapkan jika hanya dilakukan di lingkungan sekolah, sehingga tidak jarang siswa banyak mengalami hambatan dan kesulitan selama proses pembelajaran. Kondisi ini diperparah lagi dengan minimnya ketersediaan media pembelajaran baik berupa media cetak maupun elektronik.

Berdasarkan pemikiran dan pertimbangan permasalahan di atas, serta merujuk pada tujuan Kurikulum 2013 yang mengindikasikan pembelajaran yang berorientasi pada siswa, dipandang perlu mengembangkan e-modul interaktif berbasis proyek pada mata pelajaran simulasi digital siswa kelas X SMK TI Bali Global Singaraja sebagai salah satu cara memecahkan masalah pembelajaran. Mengingat selama ini dalam proses pembelajaran simulasi digital di kelas $X$ SMK TI Bali Global Singaraja, masih berpusat pada guru sehingga siswa menjadi pasif dalam proses pembelajaran dan masih menggunakan metode ceramah sebagai pilihan utama dalam mentransfer pengetahuan. Keadaan ini berimbas pada rendahnya pemahaman siswa terhadap materi pelajaran yang diterimanya.

evaluasi dan revisi terus menerus pada setiap tahapan yang dilalui. Sehingga, produk yang dihasilkan menjadi produk yang valid dan reliabel. Ketiga, hasil penelitian menunjukkan bahwa pengembangan dengan menggunakan model ADDIE, menghasilkan produk dan pembelajaran yang berkualitas.

Seperti yang dikemukakan Martins, Hoskins, Brooks, dan Bennett (2013) bahwa produk modul multimedia interaktif yang dikembangkan dengan model ADDIE hasilnya terbukti bermanfaat dan dapat meningkatkan hasil belajar peserta didik. Hal sama pula ditemukan oleh Azimi, 
Ahmadigol dan Rastegarpour (2015), Temuan penelitian menunjukkan bahwa siswa yang dilatih dengan mengikuti model ADDIE memperoleh nilai kinerja yang tinggi dibandingkan dengan metode tradisional. Ini berarti pengembangan produk yang mengikuti langkah-langkah sistematis model ADDIE, menuntun pengembang untuk menciptakan produk yang berkualitas dan bermanfaat. Model ADDIE terdiri atas 5 (lima) langkah, yaitu: (1) analisis (analyze), (2) perancangan (design), (development), (implementation) pengembangan (evaluation). Ringkasan kegiatan penelitian pengembangan divisualisasikan pada Gambar 1.

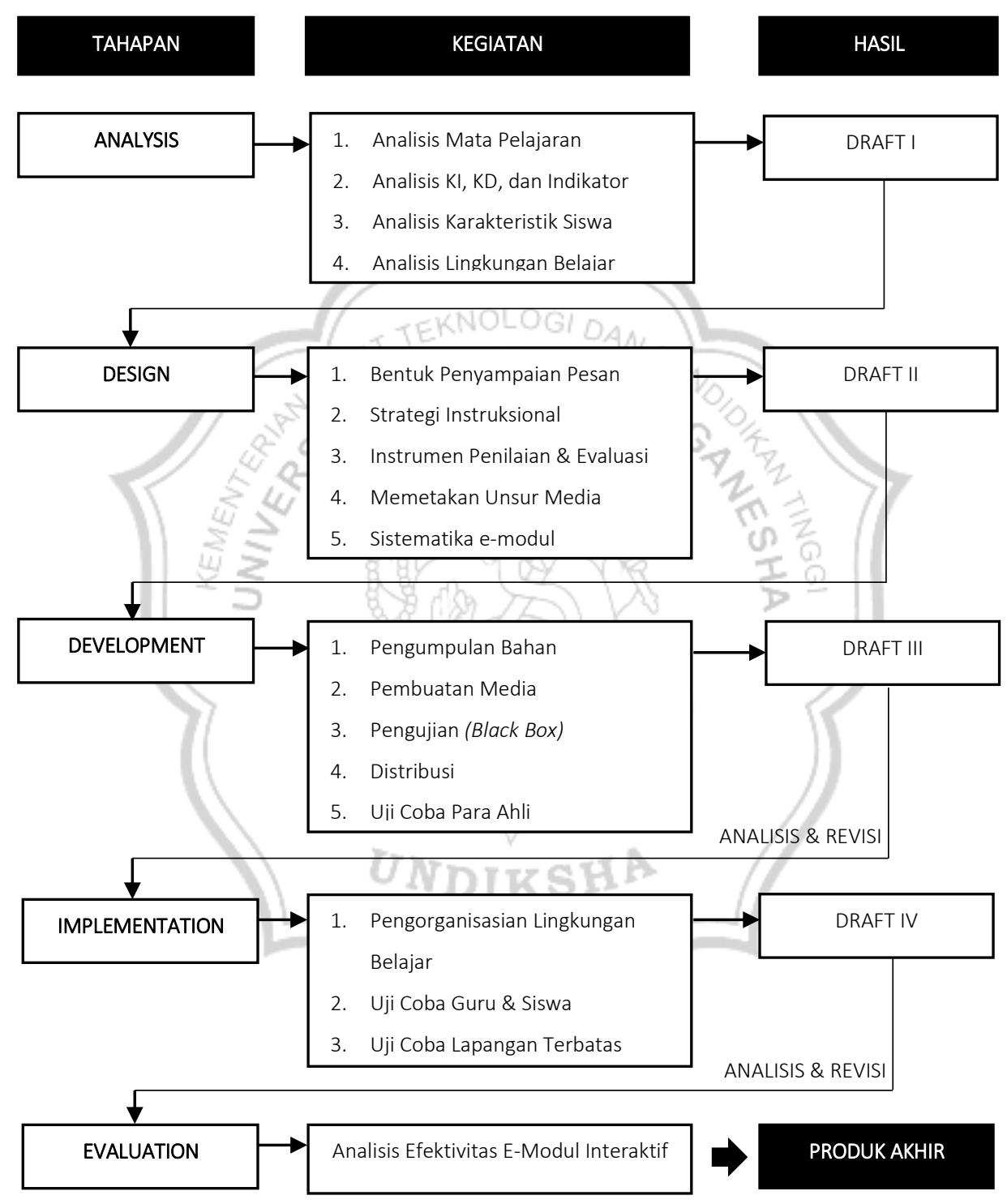

Gambar 1. Ringkasan kegiatan dalam tahapan model ADDIE

\section{Analysis (Analisis)}

Pada tahap awal dilakukan analisis bersifat deskriptif yang terdiri dari beberapa kegiatan. Pertama, analisis mata pelajaran. Kegiatan ini dilakukan untuk mengetahui kebutuhan yang diperlukan mata pelajaran yang dijadikan sebagai objek pengembangan. Informasi diperoleh dengan melakukan wawancara kepada guru mata pelajaran dan siswa. Kedua, analisis $\mathrm{KI}, \mathrm{KD}$, dan indikator. Melakukan analisis terhadap kompetensi inti, 
kompetensi dasar, dan indikator hasil belajar berdasarkan struktur Kurikulum 2013 dan silabus mata pelajaran. Ketiga, analisis karakteristik siswa. Menganalisis karakteristik siswa perlu dilakukan karena mempengaruhi komunikatif atau tidaknya produk yang dikembangkan. Menganalisis karakteristik siswa dimaksudkan untuk mengetahui ciri khas siswa secara perseorangan. Karakteristik siswa yang perlu dipertimbangkan misalnya kemampuan berfikir, kebiasaan belajar, akses terhadap teknologi dan informasi, serta kondisi ekonomi. Keempat, analisis lingkungan belajar. Menganalisis lingkungan belajar memiliki tujuan untuk mengetahui bagaimana lingkungan belajar siswa khususnya di sekolah. Lingkungan belajar yang dianalisis meliputi kenyamanan ruang belajar, interaksi antar warga sekolah dan fasilitas pendukung pembelajaran.

Dalam tahap ini data diperoleh melalui wawancara dan lembar observasi yang dilakukan kepada siswa, dan guru. Hasil analisis digunakan sebagai bahan pertimbangan dalam mengembangkan emodul interaktif yang disesuaikan dengan kondisi yang ada sebelum dilanjutkan ke tahap berikutnya. Berdasarkan hasil analisis, ditetapkan mata pelajaran yang dijadikan objek penelitian adalah mata pelajaran simulasi digital dengan sampel kelas X multimedia di SMK TI Bali Global Singaraja. Penetapan objek, sampel, dan lokasi penelitian didasarkan atas kondisi yang memungkinkan dilaksanakannya uji coba yaitu ketersediaan bahan ajar sangat minim, mayoritas siswa dapat mengoperasikan komputer dengan baik, telah menggunakan Kurikulum 2013, sarana dan prasarana cukup memadai dan jumlah sampel dianggap cukup representatif untuk dilaksanakannya uji coba.

\section{Design (Desain)}

Berdasarkan temuan hasil analisis, tahap selanjutnya yang dilaksanakan adalah desain. Kegiatan yang dilakukan pada tahap antara lain: (a) memilih bentuk penyampaian pesan, (b) membuat strategi instruksional, (c) mendesain penilaian dan instrumen evaluasi, (d) memetakan unsur media, (e) menyusun sistematika e-modul interatif seperti mendesain flowchart, struktur navigasi media, dan storyboard.

Pertama, memilih bentuk penyampaian pesan. Seiring dengan perkembangan teknologi, masyarakat saat ini lebih memilih menggunakan teknologi dalam melakukan hampir seluruh kegiatan karena dianggap lebih efektif, efisien dan praktis. Hal ini didukung oleh hasil analisis yang menjelaskan bahwa mayoritas siswa dapat mengoperasikan komputer dengan baik, sehingga bentuk penyampaian pesan yang dipilih adalah media yang berbantuan komputer. Kedua, membuat strategi instruksional. Media yang dikembangkan, dikombinasikan dengan model pembelajaran berbasis proyek di mana dalam proses pembelajarannya tugas dan kegiatan-kegiatan yang menantang dijadikan sebagai media. Tugas-tugas yang dijalankan dalam bentuk kegiatan yang menantang dan mengesankan pada diri pebelajar memiliki pengaruh positif terhadap motivasi, pemahaman, dan unjuk kerja pebelajar.

Ketiga, mendesain penilaian dan instrumen evaluasi. Dalam pengembangan, proyek digunakan sebagai salah satu teknik penilaian. Instrumen yang digunakan dalam mengukur keberhasilan proyek adalah berupa rubrik penilaian. Sebelum didistribusikan, kualitas proyek perlu divalidasi oleh ahli isi, ahli media, ahli desain pembelajaran, guru mata pelajaran, siswa perorangan, siswa kelompok kecil, dan uji lapangan terbatas untuk menjamin kualitas e-modul yang dikembangkan sebelum dipergunakan secara luas. Untuk itu, perlu dibuatkan angket penilaian bagi masing-masing validator. Angket untuk uji validator yang dibuat terdiri dari: angket untuk uji ahli isi, ahli media, ahli desain pembelajaran, guru mata pelajaran, siswa perorangan, kelompok kecil dan uji coba lapangan.

Keempat, memetakan unsur media yang akan digunakan. Tahap ini dilakukan pemetaan terhadap materi-materi yang akan disajikan dalam e-modul interaktif. Pemetaan ini penting dilakukan untuk 
mengetahui gambaran umum terhadap komponen-komponen media yang akan digunakan pada kompetensi tertentu dan memudahkan pada saat perancangan.

Kelima, menyusun sistematika emodul. Kegiatan yang dilakukan antara lain: (a) Mendesain flowchart, sering juga disebut sebagai diagram alir merupakan suatu bagan dengan simbol-simbol tertentu yang menggambarkan urutan proses secara mendetail dan hubungan antara suatu proses (instruksi) dengan proses lainnya dalam suatu program. Flowchart digunakan untuk menjelarkan alur jalannya program secara detail. (b) Mendesain struktur navigasi, merupakan alur dari suatu program. Struktur navigasi digunakan untuk merencanakan alur navigasi yang sederhana dalam aplikasi emodul. (c) Storyboard, digunakan untuk memudahkan pengembang memahami desain sajian materi dan mengidentifikasi material apa saja yang harus dibuat, didapatkan, atau disusun agar proses pengembangan sesuai dengan konsep yang telah ditentukan.

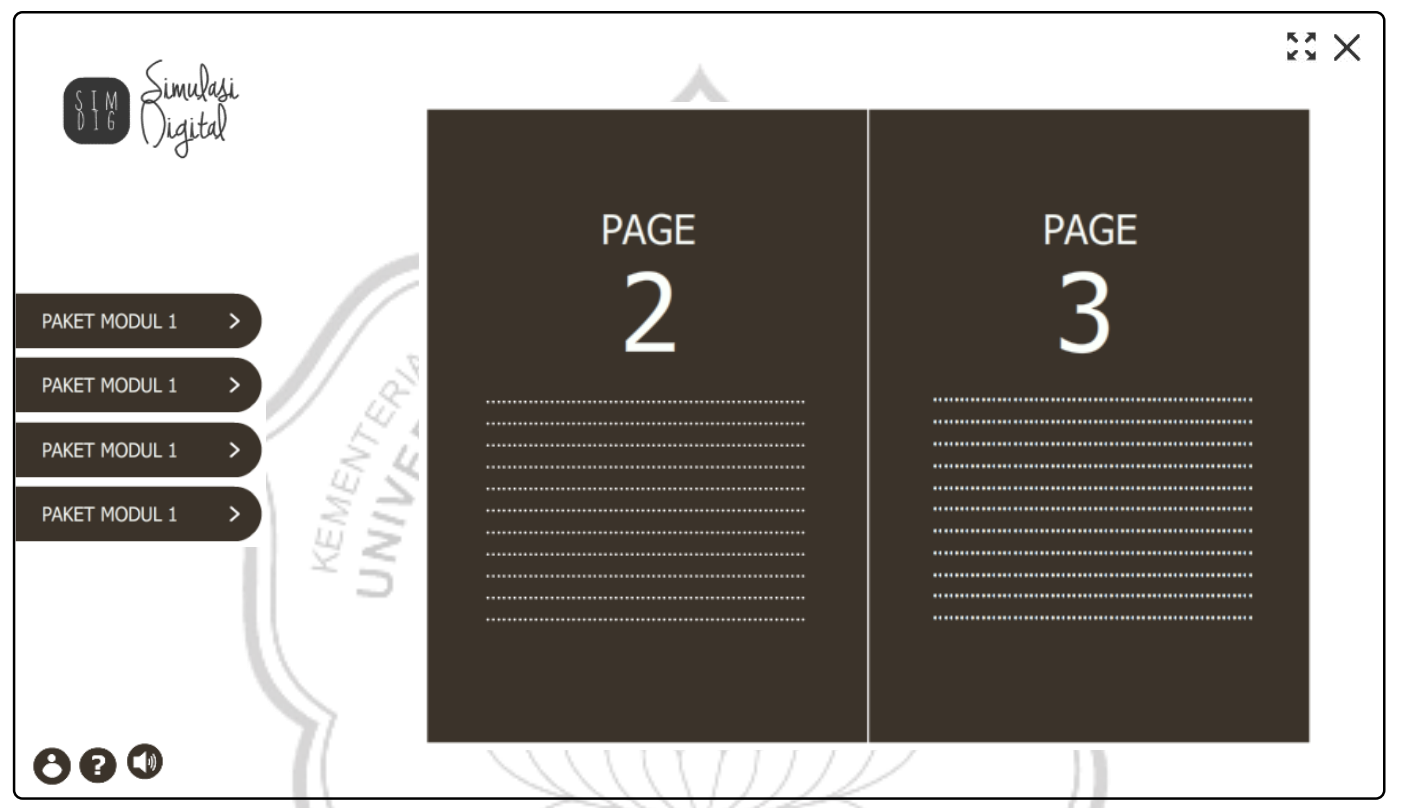

Gambar 2. Ilustrasi desain antarmuka e-modul interaktif

\section{Development (Pengembangan)}

Tahap pengembangan merupakan tahap di mana seluruh komponen yang dibutuhkan dirangkai sesuai dengan peruntukkannya masing-masing. Pengembangan dilakukan berdasarkan tahap desain yang telah direncanakan sebelumnya. Kegiatan yang dilakukan pada tahap pengembangan, akan diuraikan sebagai berikut.

Pertama, pengumpulan bahan. Jenis bahan yang dikumpulkan erat kaitannya dengan karakteristik dan kebutuhan materi pembelajaran. Materi pada masing-masing bab disajikan dengan komponen multimedia yang berbeda-beda sesuai dengan tingkat keabstrakkan materi. Komponen multimedia yang mendukung penyampaian materi pembelajaran yaitu teks, gambar/grafik, audio, video, dan animasi.

Kedua, pembuatan media. Tahap pembuatan merupakan tahap di mana seluruh komponen yang diperlukan dibuat dan digabungkan. Pembuatan dilakukan mengikuti flowchart, struktur navigasi, dan storyboard yang telah direncanakan pada tahap desain. Secara garis besar, bahan ajar yang dikembangkan terdiri atas 2 (dua) halaman yaitu halaman opening (pembuka) dan halaman utama.

Ketiga, pengujian. Pada tahap ini, produk yang telah selesai dikembangkan selanjutnya diuji. Pengujian ini dilakukan untuk mencari berbagai kesahalan (bug) 
seperti kesalahan penulisan action script yang menyebabkan kegagalan eksekusi terhadap perintah hingga kesalah urutan pemanggilan suatu objek, dalam hal ini adalah urutan tugas, materi atau evaluasi. Metode pengujian yang digunakan adalah metode black box.

Keempat, distribusi. Tahap distribusi merupakan tahap produk pengembangan direproduksi dan didistribusikan kepada pengguna untuk digunakan dalam rangka evaluasi. Ada 3 (tiga) kegiatan dalam tahap distribusi yaitu: a) pembuatan buku panduan, b) pembuatan kemasan, dan c) penggandaan bahan ajar dan buku panduan.

Kelima, uji coba produk. Pada tahap ini dilakukan pengujian berdasarkan tinjauan dari beberapa ahli, antara lain: ahli isi, ahli desain pembelajaran, dan ahli media. Data dalam uji coba diperoleh dengan menggunakan instrumen angket untuk mengetahui kualitas e-modul interaktif yang dikembangkan. Hasil uji coba para ahli ini merupakan masukan untuk dilakukannya revisi sehingga pada akhirnya diperoleh produk yang valid.

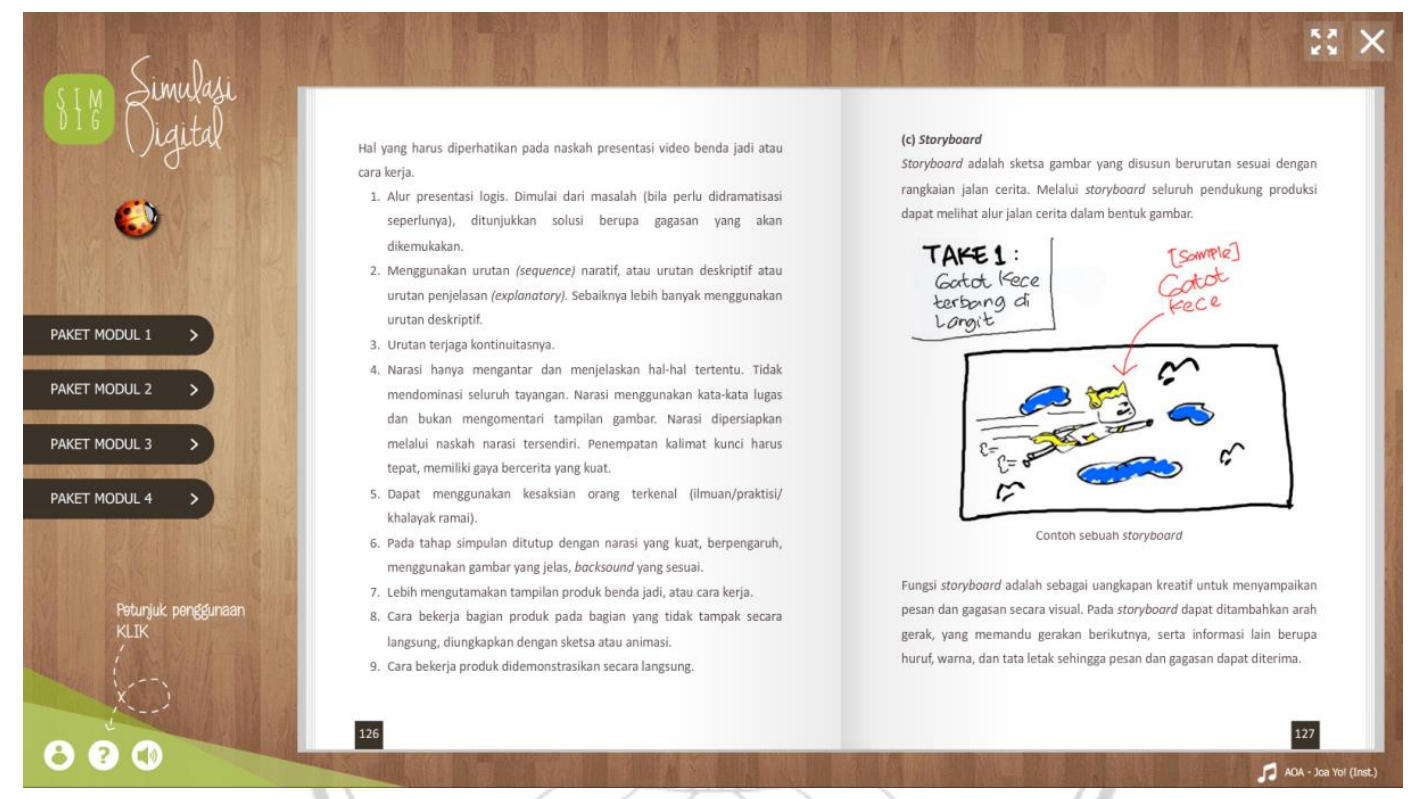

Gambar 3. Antarmuka e-modul interaktif

\section{Implementation (Implementasi)}

Pada tahap ini, hasil produk yang dikembangkan diterapkan dalam pembelajaran untuk mengetahui pengaruhnya terhadap hasil belajar siswa. Tahap ini terdiri dari tiga kegiatan. Pertama, pengorganisasian lingkungan belajar. Tujuan dari kegiatan ini adalah untuk memastikan bahwa kelas dan fasilitas yang dibutuhkan telah tersedia sebelum dilakukan uji coba lapangan. Langkah ini dilaksanakan untuk membantu mencapai pengiriman pesan (proses pembelajaran) berjalan efektif tanpa masalah apapun. Pengorganisasian lingkungan belajar dilakukan pada laboratorium multimedia SMK TI Bali Global Singaraja.

Kedua, uji coba produk. Pada tahap ini dilakukan pengujian berdasarkan tinjauan dari beberapa responden, antara lain: (1) uji guru mata pelajaran, (2) 3 (tiga) orang siswa dalam uji coba perorangan, dan (3) 10 (sepuluh) orang siswa dalam uji coba kelompok kecil.

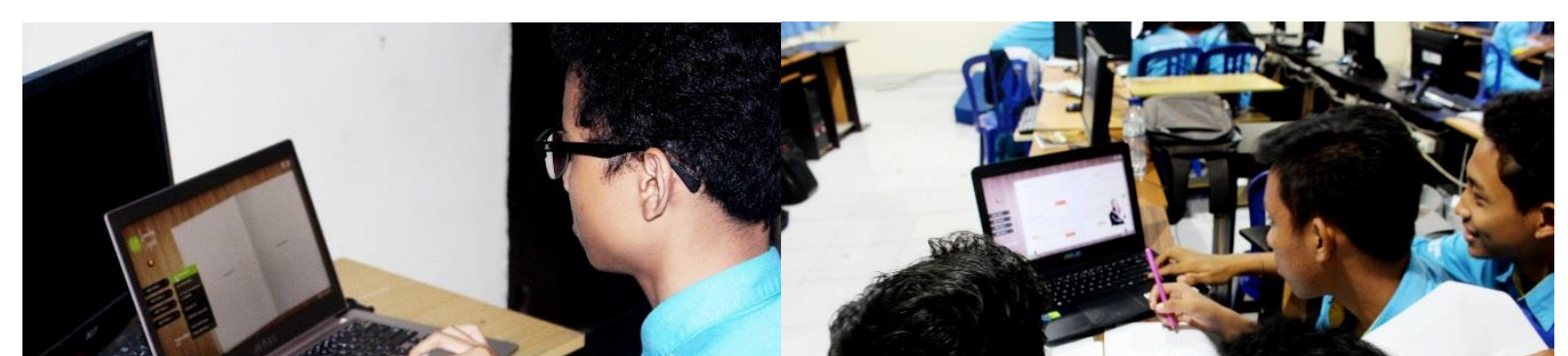


(a)

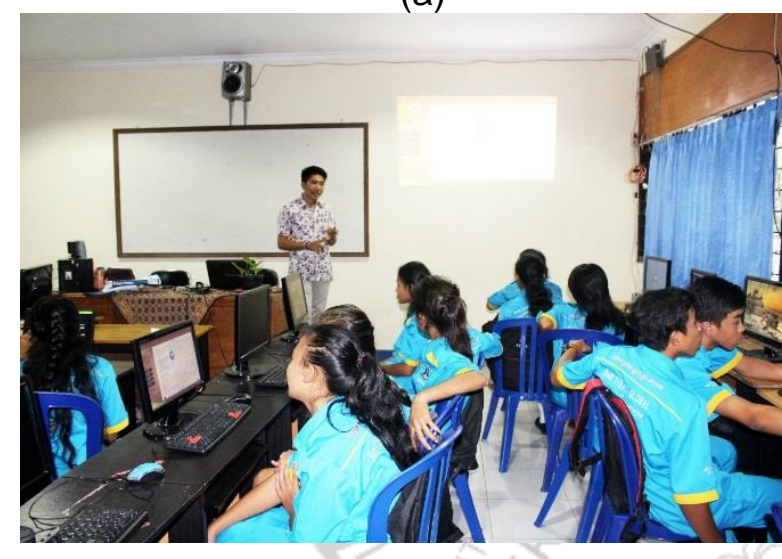

(c) (b)

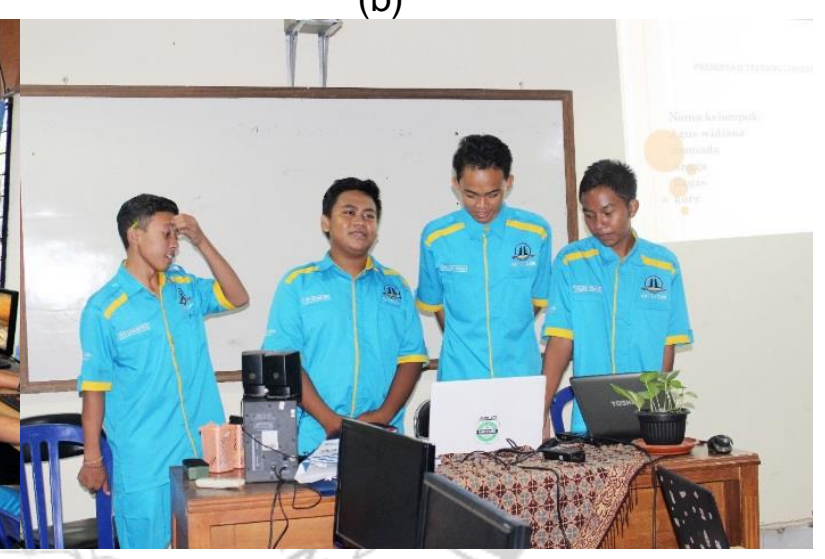

(d)

Gambar 4. (a) Siswa menggunakan e-modul ineteraktif berbasis proyek secara mandiri, (b) Siswa menggunakan e-modul interaktif berbasis proyek dalam kelompok kecil, (c) uji lapangan terbatas, (d) presentasi proyek.

Ketiga, uji coba lapangan terbatas. Uji lapangan merupakan evaluasi yang dilakukan terhadap suatu media pembelajaran yang sudah selesai dikembangkan tapi masih membutuhkan atau memungkinkan untuk direvisi akhir. Dalam uji coba, menggunakan subjek coba siswa dalam satu kelas. Kelas yang dipilih dalam uji lapangan adalah 21 siswa kelas $X$ multimedia SMK TI Bali Global Singaraja. Data dalam uji coba tahap kedua ini diperoleh dengan menggunakan instrumen angket untuk mengetahui kualitas e-modul interaktif yang dikembangkan serta revisi produk yang harus dilakukan.

\section{Evaluation (Evaluasi)}

Evaluasi adalah proses untuk melihat apakah produk yang dikembangkan berhasil, dan sesuai dengan harapan awal atau tidak. Tahap evaluasi dilakukan pada setiap empat tahap sebelumnya. Evaluasi yang terjadi pada setiap empat tahap tersebut dinamakan evaluasi formatif, karena tujuannya untuk kebutuhan revisi. Evaluasi formatif yang dilakukan antara lain (1) uji para ahli, (2) uji guru mata pelajaran, (3) uji perorangan, (4) uji kelompok kecil, dan (5) uji lapangan. Evaluasi juga dilakukan pada tahap akhir pengembangan produk untuk mengetahui efektivitas produk yang dikembangkan. Cara mengetahui keefektifan produk, digunakan uji-t melalui metode pra eksperimen menggunakan pretest dan posttest.

\section{HASIL DAN PEMBAHASAN}

Masalah yang diangkat dalam penelitian pengembangan ini adalah terhambatnya proses pembelajaran di SMK TI Bali Global karena kurangnya 
alokasi waktu yang disediakan, materi pembelajaran yang masih belum tersusun sesuai dengan tuntutan mata pelajaran, dan dalam proses pembelajaran belum sepenuhnya menggunakan model yang inovatif.

Teknologi dapat digunakan sebagai salah satu alternatif untuk mengatasi masalah ini, salah satunya adalah dengan mengembangkan e-modul interaktif berbasis proyek. Pemanfaatan teknologi ini dapat digunakan sebagai media dalam menjembatani komunikasi yang diinginkan dalam pembelajaran. E-modul interaktif berbasis proyek didesain agar mampu mengakomodasi keberagaman kemampuan belajar siswa dan mengatasi kurangnya alokasi waktu.

Unsur inovatif dalam bahan ajar adalah adanya proyek-proyek, di mana tugas dan kegiatan-kegiatan yang menantang digunakan sebagai media dalam pembelajaran. Tahap pengembangan bahan ajar e-modul interaktif menggunakan model ADDIE yang terdiri atas beberapa tahap, yaitu: (1) Analysis (analisis) yang meliputi proses: a) analisis mata pelajaran, b) analisis $\mathrm{KI}, \mathrm{KD}$, dan indikator, c) analisis kebutuhan pebelajar, d) analisis lingkungan belajar dan e) analisis kendala., (2) Design (desain) yang meliputi proses: a) memetakan unsur media, b) mendesain flowchart, c) merancang struktur navigasi media, dan d) mendesain storyboard., (3) Development (pengembangan) yang meliputi proses: a) pengumpulan bahan, b) pembuatan media, c) pengujian, d) distribusi, e) pengembangan instrumen evaluasi, dan f) uji coba ahli, (4) Implementation (implementasi) yang meliputi proses: a) pengorganisasian lingkungan belajar, dan b) uji lapangan dengan sampel 21 siswa kelas $X$ Multimedia SMK TI Bali Global Singaraja, dan (5) Evaluation (evaluasi), dilakukan pada keempat tahap sebelumnya yang terdiri dari dua jenis evaluasi yaitu: a) evaluasi formatif, yang diberikan pada para ahli dan guru mata pelajaran dalam bentuk kuesioner, dan b) evaluasi sumatif, yang dilakukan pada saat uji coba lapangan dengan menggunakan soal pretest dan posttest.

Hasil review ahli isi menujukkan validitas bahan ajar dari aspek isi adalah sangat baik dengan perolehan persentase sebesar 98\%. Hasil ini mengindikasikan bahwa isi bahan ajar mengandung fakta, konsep, prinsip, dan prosedur yang sesuai dan layak dibelajarkan kepada siswa. Buku panduan guru memperoleh persentase sebesar $100 \%$ dengan kualifikasi sangat baik. Revisi yang dilakukan dalam tahap ini adalah 1) melengkapi sumber pada gambar, tabel, video, dan animasi, dan 2) penambahan animasi simulasi pada materi

Hasil review ahli desain pembelajaran menunjukkan validitas bahan ajar dari aspek desain adalah sangat baik dengan perolehan persentase sebesar $100 \%$. Hasil ini memiliki arti bahwa bahan ajar e-modul interaktif telah memnuhi kelayakan aspek desain pembelajaran, strategi penyampaian pesan, desain antarmuka, dan keotentikan tugas-tugas proyek yang disajikan dalam bahan ajar. Buku panduan guru yang telah direview oleh ahli desain pembelajaran memperoleh persentase sebesar $100 \%$ dengan kualifikasi sangat baik. Revisi yang dilakukan pada tahap ini antara lain, 1) pemotongan materi pada bagian-bagian tertentu, dan 2) menambahkan informasi untuk menjamin kepadatan informasi pada saat digunakan

Hasil review ahli media menunjukkan validitas bahan ajar dari aspek media adalah sangat baik dengan persentase sebesar $100 \%$. Hasil ini mengindikasikan bahwa pengaturan navigasi, desain antarmuka, teks, penggunaan fitur-fitur multimedia seperti gambar, animasi, audio, dan video, kemudahan penggunaan dan pengemasan sudah memenuhi standar dan layak digunakan dalam pembelajaran. Buku panduan guru memperoleh persentase sebesar $100 \%$ dengan kualifikasi sangat baik. Revisi yang dilakukan pada tahap ini adalah, 1) penambahan sumber pada gambar, animasi, tabel, dan video, 2) penambahan waktu pengerjaan kuis, dari 2 menit menjadi 20-30 menit, 3) memberi identitas pada cover buku panduan, 4) menambahkan cover pada bagian dalam 
buku panduan, dan 5) memberi informasi kriteria ketuntasan minimal (KKM) pada buku panduan.

Hasil review guru mata pelajaran menunjukkan validitas bahan ajar sangat baik dengan perolehan persentase sebsar $93,5 \%$. Buku panduan guru memperoleh tingkat validitas sangat baik dengan peroleh persentase sebesar $98 \%$.

"Secara keseluruh, e-modul interaktif sangat baik dan dikemas secara menarik. Desain cover dan pemilihan warna pada buku panduan sudah tepat dan menarik." Guru mata pelajaran.

Revisi yang dilakukan pada tahap ini antara lain, 1) memperbaiki penulisan tujuan pembelajaran, dan 2) menambahkan identitas tingkat/kelas pada buku panduan.

Hasil uji perorangan, kelompok kecil, dan lapangan menunjukkan tingkat validitas bahan ajar adalah sangat baik dengan perolehan persentase masingmasing adalah $92.62 \%,-93.5 \%$, dan $89.45 \%$.

"Secara keseluruhan hampir semua yang ditampilkan sangat interaktif dan bagus". Siswa dalam uji perorangan

"Sangat menarik, tampilan gambarnya sangat menarik, proporsi letak menu sesuai, materinya mudah dipahami, informasi yang disajikan lengkap." Siswa dalam uji kelompok kecil.

"Materi dapat dipelajari dengan baik dan masuk ke otak. Karena sangat santai dengan metode pembelajaran yang kekinian." Siswa dalam uji lapangan terbatas.

Hasil ini menunjukkan, kejelasan materi, kemenarikan, dan kemudahan penggunaan sudah dianggap layak bila digunakan oleh siswa. Pada tahap ini tidak dilakukan revisi, karena tidak ada saransaran yang dinyatakan oleh siswa.

Hipotesis diuji menggunakan uji-t untuk mengetahui perbedaan skor ratarata hasuk antar skor pretest dan posttest.
Hipotesis yang diuji yaitu: 1) $\mathrm{H}_{0}$ : tidak terdapat perbedaan yang significant antara nilai rata-rata hasil belajar siswa sebelum dan sesudah menggunakan e-modul interaktif berbasis proyek, dan 2) $\mathrm{H}_{1}$ : terdapat perbedaan yang significant antara nilai rata-rata hasil belajar siswa sebelum dan sesudah menggunakan e-modul interaktif berbasis proyek. Berdasarkan hasil uji-t dua sampel berpasangan (paired sample $t$-test) menunjukkan bahwa, signifikansi yang diperoleh adalah 0.000 kurang dari nilai signifikansi yang telah ditetapkan yaitu 0.05 sehingga $\mathrm{H}_{0}$ ditolak. Ini berarti, terdapat perbedaan yang signifikan antara nilai rata-rata hasil belajar siswa sebelum dan sesudah menggunakan e-modul interaktif berbasis proyek.

Tingkat keefektifan bahan ajar e-modul interaktif dalam pembelajaran, dihitung dengan menggunakan gain score ternormalisasi. Hasil akhir gain score adalah 0.70, selanjutnya nilai tersebut dikonversi ke dalam kriteria gain score ternormalisasi dan berada pada kategori tinggi. Jadi dapat disimpulkan, keefektifan bahan ajar e-modul interaktif berbasis proyek dalam meningkatkan hasil belajar siswa adalah tinggi.

\section{PENUTUP \\ Simpulan}

Pengembangan e-modul interaktif berbasis proyek pada mata pelajaran simulasi digital dikembangkan dengan menggunakan model ADDIE yang terdiri atas beberapa tahap, yaitu: (1) Analysis (analisis), (2) Design (desain), Development (pengembangan), Implementation (implementasi), dan (5) Evaluation (evaluasi). Berdasarkan penilaian yang diberikan oleh para ahli, guru, serta pendapat siswa, maka bahan ajar yang dikembangkan layak digunakan dalam proses pembelajaran.

E-modul interaktif berbasis proyek terbukti valid berdasarkan serangkaian pengujian oleh para ahli, praktis berdasarkan hasil implementasi di 
lapangan oleh guru mata pelajaran dan siswa, dan efektif berdasarkan hasil uji-t dua sampel berpasangan (paired samples test).

\section{Saran}

Berdasarkan hasil penelitian dan pembahasan terhadap media yang dikembangkan berupa e-modul interaktif berbasis proyek, dapat diajukan beberapa saran sebagai berikut.

1. E-modul interaktif berbasis proyek dikembangkan berdasarkan hasil studi pendahuluan terhadap siswa di SMK TI Bali Global Singaraja, sehingga bila digunakan di sekolah lain dengan karakteristik siswa yang berbeda, maka disarankan untuk melakukan perubahan seperlunya sesuai dengan kebutuhan.

\section{DAFTAR RUJUKAN}

Azimi K, Ahmadigol J. Rastegarpour $\mathrm{H}$. (2015). A Survey of the Effectiveness of Instructional Design ADDIE and Multimedia on Learning Key Skills of Futsal. J. Educ. Manage. Stud., 5(3): 180-186. Terdapat pada http://jems. science-line.com. Diakses 1 Desember 2016.

Budiarti, S., Nuswowati, M., \& Cahyono, E. (2016). Guided inquiry berbantuan e-modul untuk meningkatkan keterampilan berfikir kritis. Journal of innovative Science Education, 5(2), 144-151. Terdapat pada http://journal.unnes.ac.id/sju/index.php /jise/article/view/14598/7686. Diakses 2 Januari 2016.

Depdiknas. (2008). Panduan Pengembangan Bahan Ajar.

Hussain, I. (2012). Use of constructivist approach in higher education: an instructors' observation. Scientific Research, 3(2), 179-184. Terdapat pada http://file.scirp.org/pdf/CE201202 0001_53207289.pdf. Diakses 29 Desember 2016.
2. Produk yang dihasilkan dalam pengembangan ini adalah e-modul interaktif berbasis proyek yang proses pembuatannya menggunakan software Adobe Flash. Disarankan dalam pengembangan produk selanjutnya, agar mengembangkan jenis media lain yang lebih inovatif seperti e-learning, video pembelajaran, atau bentuk media lainnya, sehingga nantinya sekolah akan memiliki sumber belajar dalam bentuk yang lebih beragam.

3. Penelitian pengembangan ini dilakukan hanya terbatas pada uji efetivitas (uji-t). Oleh karena itu perlu dilakukan penelitian lebih lanjut mengenai kelayakan media sampai dengan hasil belajar yang dicapai siswa melalui penelitian kuasi eksperimen dengan menggunakan kelas pembanding.

\section{ENDID//}

Ibnu, B. T. (2014). Mendesain Model Pembelajaran Inovatif, Progresif, dan Kontekstual - Konsep, Landasan, dan Implementasinya pada Kurikulum 2013 I(Kurikulum Tematik Integratif/KTI). Jakarta: Kencana.

Martin F., Hoskins, O. J., Brooks, R., \& Bennet, T. (2013). Development of an interactive multimedia instructional module. The Journal of Applied Instructional Design, 3(3), 5-18. Terdapat pada http://www.jaidpub.org /wp-content/uploads/2013/12/Martin EtAl-JAID-Dec2013.pdf. Diakses 18 April 2016.

Nugraha, A., Subarkah, C. Z., \& Sari. (2015). Penggunaan e-module pembelajaran pada konsep sifat koligatif larutan untuk mengembangkan literasi kimia siswa. Prosiding Simposium Nasional Inovasi dan Pembelajaran Sains, 201-204. Terdapat pada http://portal.fi.itb.ac.id/snips2015/files/s nips_2015_agung_nugraha_1c124c09c 74cfa24b159a4272d7c4c00.pdf.

Diakses 16 April 2016.

Peraturan Menteri Pendidikan dan Kebudayaan Republik Indonesia Nomor 
65 Tahun 2013 Tentang Standar Proses Pendidikan Dasar dan Menengah.

Prabawa, D. G. A. P. (2013). Pengembangan bahan ajar multimedia berbasis proyek pada mata pelajaran produksi audio dan video kelas XI di SMK Negeri 1 Sukasada. Tesis. Tidak dipublikasikan. Universitas Pendidikan Ganesha.

Smeets, D. J. H. \& Bus, A. G. (2014). The interactive animated e-book as a word learning device for kindergartners.
Applied Psycholinguistics, 1(1), 1-22. Terdapat pada http://www.ijiet.org/ papers/481-S00008.pdf. Diakses 28 Januari 2016.

Tegeh, I M., Jampel, I N., \& Pudjawan, K. (2014). Model penelitian pengembangan. Yogyakarta: Graha IImu.

Undang-undang Republik Indonesia Nomor 20 Tahun 2003 Tentang Sistem Pendidikan Nasional. 